\title{
Kinetics of Hydride Transfer Reactions from Hydrosilanes to Carbenium Ions. Substituent Effects in Silicenium Ions ${ }^{\dagger, \ddagger}$
}

\author{
Herbert Mayr,*,8 Nils Basso, and Gisela Hagen ${ }^{\S}$ \\ Contribution from the Institut für Chemie der Medizinischen Universität zu Lübeck, \\ D-2400 Lübeck, Germany. Received August 20, 1991
}

\begin{abstract}
Rates of hydride transfer from hydrosilanes $H S i R^{1} R^{2} R^{3}$ with widely varying substitution to para-substituted diarylcarbenium ions have been measured in dichloromethane solution. Generally the reactions follow a second-order rate law, $-\mathrm{d}\left[\mathrm{Ar}_{2} \mathrm{CH}^{+}\right] / \mathrm{d} t=k_{2}\left[\mathrm{Ar}_{2} \mathrm{CH}^{+}\right]\left[\mathrm{HSiR}{ }^{1} \mathrm{R}^{2} \mathrm{R}^{3}\right]$, and $k_{2}$ is independent of the degree of ion-pairing and the nature of the counterion (exceptions are reported). The reaction rates are almost independent of solvent polarity. Kinetic isotope effects exclude an SET-type mechanism and are in accord with a polar mechanism with rate-determining formation of silicenium ions. The reactivities of para-substituted aryldimethylsilanes are linearly correlated with $\sigma_{\mathrm{p}}(\rho=-2.46)$, not with $\sigma_{\mathrm{p}}^{+}$. In the series $\mathrm{H}_{3} \mathrm{SiHex}, \mathrm{H}_{2} \mathrm{SiHex}_{2}, \mathrm{HSiHex}_{3}$, the relative reactivities are 1.00:155:7890, and in the corresponding phenyl series the reactivity increase is much smaller $\left(\mathrm{H}_{3} \mathrm{SiPh}: \mathrm{H}_{2} \mathrm{SiPh}_{2}: \mathrm{HSiPh}_{3}=1.00: 17.2: 119\right)$. As a consequence, trihexylsilane is approximately two orders of magnitude more reactive than triphenylsilane though hexylsilane and phenylsilane show similar reactivities. Tris(trimethylsilyl)silane is just slightly more reactive than trimethylsilane. Replacement of hydrogen by chlorine reduces the reactivity by one order of magnitude. Variation of the electrophilicities of the hydride abstractors does not affect the relative reactivities of the silanes, i.e., constant selectivity (Ritchie-type) relationships are encountered. Correlation equations are given, which permit the calculation of hydride transfer rates from hydrosilanes to any carbenium ion on the basis of $\mathrm{p} K_{\mathrm{R}^{+}}$ values or the ethanolysis rate constants of the corresponding alkyl chlorides.
\end{abstract}

\section{Introduction}

Hydrosilanes are well-known reducing agents for a variety of functional groups. ${ }^{1}$ When these reactions are performed in Bronsted or Lewis acidic media, hydride transfer from silicon to positively charged carbon with formation of silicenium ions takes place (Scheme I). ${ }^{1}$ Despite their thermodynamic stability, silicenium ions are very short lived reaction intermediates, and reports on the observation of persistent silicenium ions in the condensed phase ${ }^{2}$ have been rejected. ${ }^{3}$ Information on the stabilities of silicenium ions has been obtained from quantum chemical calculations, ${ }^{4}$ gas-phase studies, ${ }^{5 a-e}$ electrochemical experiments, ${ }^{5 f}$ and kinetic investigations of hydride abstractions from hydrosilanes. ${ }^{6}$

A qualitative order of hydride-donating abilities of hydrosilanes $\left(\mathrm{HSiEt}_{3}>\mathrm{HSi}^{n} \mathrm{Oct}_{3} \approx \mathrm{H}_{2} \mathrm{SiEt}_{2}>\mathrm{H}_{2} \mathrm{SiPh}_{2} \approx \mathrm{HSiPh}_{3}>\mathrm{H}_{3} \mathrm{SiPh}\right.$ ) was reported by Carey in $1968 .^{7}$ Kinetic investigations of the hydride transfer reactions from triarylsilanes and aryldimethylsilanes to the tris(2,6-dimethoxyphenyl)carbenium ion in acetic acid provided $\rho$-values of -1.84 and -1.01 , respectively. ${ }^{7}$ The small magnitude of these reaction constants was explained by nucleophilic solvent assistance in replacement of hydride from silicon.?

Extensive kinetic studies on hydride transfer reactions from trisubstituted silanes to the trityl cation and tropylium ion have been performed by Chojnowski. ${ }^{\text {a }, \mathrm{b}}$ According to Figure 1, replacement of methyl in $\mathrm{HSiMe}_{3}$ by either $\mathrm{Et}, \mathrm{Ph}, \mathrm{EtS}$, or $\mathrm{Cl}$ reduces the reactivity toward the trityl cation to a various extent. Since the nature of the negative counterion $\left(\mathrm{SbF}_{6}{ }^{-}, \mathrm{AsF}_{6}{ }^{-}, \mathrm{PF}_{6}^{-}\right.$, $\left.\mathrm{BF}_{4}^{-}, \mathrm{SbCl}_{6}, \mathrm{FeCl}_{4}^{-}\right)$hardly affected the rates in dichloromethane, an $\mathrm{S}_{\mathrm{N}} 2-\mathrm{Si}$ pathway has been excluded. ${ }^{6 \mathrm{a}}$ The structural effects on reactivity and the kinetic isotope effects $\left(k\left(\mathrm{HSiR}_{3}\right) / k\left(\mathrm{DSiR}_{3}\right)\right.$ $=1.4-1.5$ ) have been interpreted in terms of the mechanism in eq 1 , with rate-limiting single-electron transfer, followed by a rapid hydrogen shift. ${ }^{6 a}$

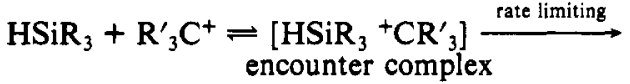

$$
\begin{aligned}
& \left\{\mathrm{R}_{3} \mathrm{SiH}^{\bullet+} \cdot \mathrm{CR}^{\prime}\right\} \rightarrow{ }^{+} \mathrm{SiR}_{3}+\mathrm{HCR}_{3}^{\prime}
\end{aligned}
$$

\footnotetext{
${ }^{\dagger}$ Dedicated to Professor F. W. Lichtenthaler on the occasion of his 60 th birthday.

${ }^{\ddagger}$ In part presented at the European Symposium on Organic Reactivity, ESOR III, in Gøteborg, Sweden, July, 7-12, 1991.

New address: Institut für Organische Chemie und Biochemie, Petersenstrasse 22, D-6100 Darmstadt, Germany.
}

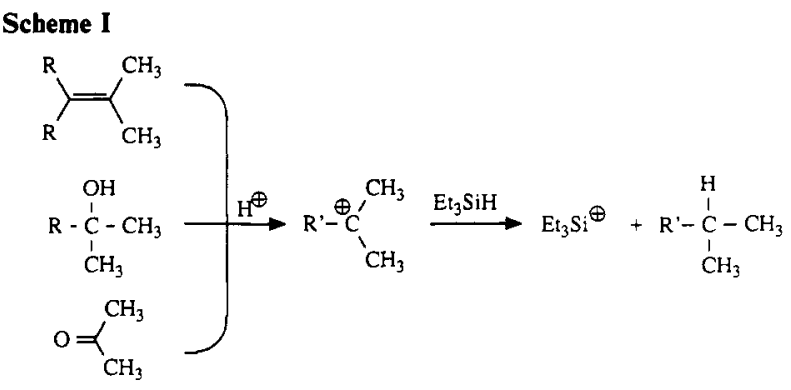

Table I. Second-Order Rate Constants for the Reaction of the $\operatorname{Bis}\left(p\right.$-anisyl)carbenium Ion $\left(\mathrm{An}_{2} \mathrm{CH}^{+}, 0.11 \mathrm{mmol} \cdot \mathrm{L}^{-1}\right)^{a}$ with Dimethylphenylsilane in the Presence of Various Lewis Acids $\left(\mathrm{CH}_{2} \mathrm{Cl}_{2},-70^{\circ} \mathrm{C}\right)$

\begin{tabular}{lccc}
\hline Lewis acid & $\begin{array}{c}\text { Lewis acid }]_{0}, \\
\mathrm{mmol} \cdot \mathrm{L}^{-1}\end{array}$ & $\begin{array}{c}{\left[\mathrm{HSiMe}_{2} \mathrm{Ph}\right]_{0},} \\
\mathrm{mmol} \cdot \mathrm{L}^{-1}\end{array}$ & $\begin{array}{c}k_{2}, \\
\mathrm{~L} \cdot \mathrm{mol}^{-1} \cdot \mathrm{s}^{-1}\end{array}$ \\
\hline $\mathrm{TiCl}_{4}$ & 3.26 & 0.432 & 1.20 \\
& 7.61 & 0.436 & 1.15 \\
$\mathrm{Me}_{3} \mathrm{SiOTf}$ & 16.1 & 0.432 & 1.12 \\
& 1.11 & 7.14 & 1.11 \\
$\mathrm{BCl}_{3}$ & 1.11 & 17.8 & 1.10 \\
& 3.04 & 0.432 & $169^{b}$ \\
& 8.69 & 0.872 & $470^{b}$ \\
& 43.5 & 0.432 & $1121^{b}$ \\
\hline
\end{tabular}

${ }^{a}$ Counterion $=\mathrm{TiCl}_{5}^{-}$, OTf ${ }^{-}$, or $\mathrm{BCl}_{4}^{-}$, depending on Lewis acid employed. ${ }^{b}$ Pseudo-second-order rate constant.

In a series of papers, we have reported that the reactivities of various classes of nucleophiles toward para-substituted diaryl-

(1) Reviews: (a) Nagai, Y. Org. Prep. Proced. Int. 1980, 12, 13. (b) Kursanov, D. N.; Parnes, Z. N.; Loim, N. M. Synthesis 1974, 633. (c) Carey, F. A. Intra-science Chem. Rept. 1973, 7, 55. (d) Kursanov, D. N., Parnes, Z. N. Russ. Chem. Rev. 1969, 38, 812. (e) Keinan, E. Pure Appl. Chem. 1989, 61, 1737. (f) Hajós, A. In Houben-Weyl, Methoden der Organischen Chemie, 4th ed.; Georg Thieme Verlag: Stuttgart, 1981; Vol. IV/1d, pp 1-487. (g) Pawlenko, S. In Houben-Weyl, Methoden der Organischen Chemie, 4th, ed.; Georg Thieme Verlag: Stuttgart, 1980; Vol. XIII/5, pp 350-361. (h) Colvin, E. W. Silicon Reagents in Organic Synthesis; Academic Press: London, 1988.

(2) (a) Lambert, J. B.; McConnell, J. A.; Schulz, W. J., Jr. J. Am. Chem. Soc. 1986, 108, 2482. (b) Lambert, J. B.; Schulz, W. J., Jr. J. Am. Chem. Soc. 1983, 105, 1671. (c) Lambert, J. B.; Schulz, W. J., Jr.; McConnell, J. A.: Schilf, W. J. Am. Chem. Soc, 1988, 110, 2201. (d) Lambert, J. B.; McConnell, J. A.; Schilf, W.; Schulz, W. J., Jr. J. Chem. Soc., Chem. Commun. 1988, 455. (e) Lambert, J. B.; Schilf, W. J. Am. Chem. Soc. 1988, 110, 6364 . 


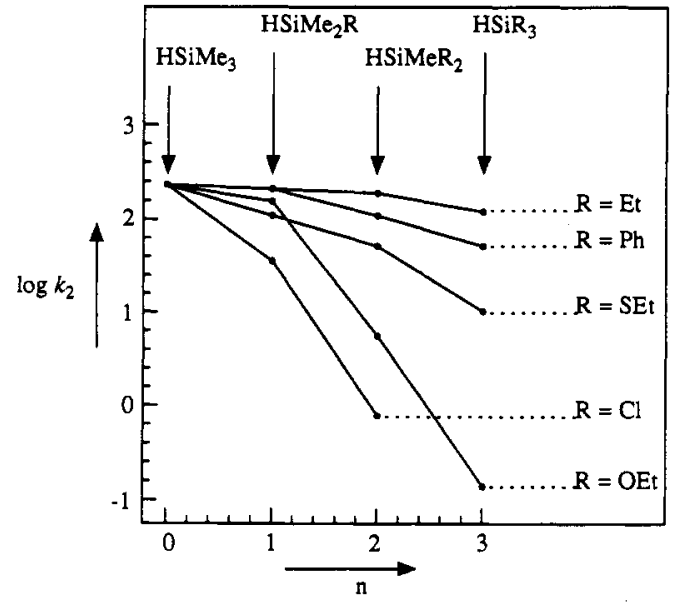

Figure 1. Rate constants for the hydride transfer reactions from $\mathrm{HSiMe}_{3-n} \mathrm{R}_{n}$ to $\mathrm{Ph}_{3} \mathrm{C}^{+}\left(\mathrm{CH}_{2} \mathrm{Cl}_{2}, 25^{\circ} \mathrm{C}\right){ }^{6 \mathrm{a}}$

Scheme II

Kinetic Method

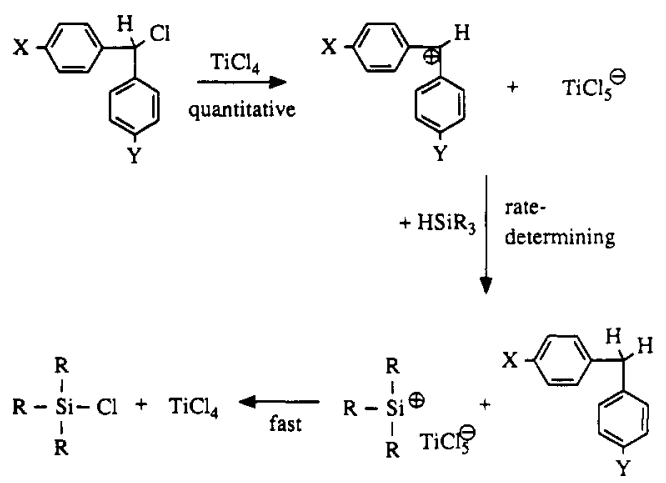

Abbreviations
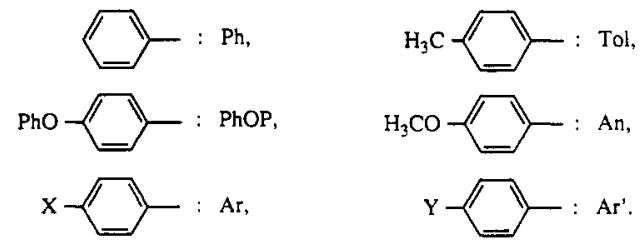

carbenium ions follow well-behaved linear free energy relationships, which allow the construction of a nucleophilicity scale

(3) (a) Prakash, G. K. S.; Keyaniyan, S.; Aniszfeld, R.; Heiliger, L.; Olah, G. A.; Stevens, R. C.; Choi, H.-K.; Bau, R. J. Am. Chem. Soc. 1987, 109 , 5123. (b) Olah, G. A.; Heiliger, L.; Li, X.-Y.; Prakash, G. K. S. J. Am. Chem. Soc. 1990, 112, 5991. (c) Wang, N.; Hwu, J. R.; White, E. H. J. Org. Chem 1991, 56, 471. (d) Eaborn, C. J. Organomet. Chem. 1991, 405, 173.

(4) (a) Hopkinson, A. C.; Lien, M. H. Can. J. Chem. 1989, 67, 991. (b) Apeloig, Y. In Heteroatom Chemistry; Block, E., Ed.; VCH-Verlagsgesellschaft: Weinheim, 1990; p 27. (c) Apeloig, Y. In The Chemistry of Organic Silicon Compounds; Patai, S., Rappoport, Z., Eds.; Wiley Interscience: New York, 1989; Chapter 2 and literature cited therein. (d) Hopkinson, A. C.; Lien, M. H. J. Org. Chem. 1981, 46, 998. (e) Apeloig, Y.; Schleyer, P. v. R. Tetrahedron Lett. 1977, 18, 4647. (f) Apeloig, Y.; Godleski, S. A.; Heacock, D. J.: McKelvey, J. M. Tetrahedron Lett. 1981, 22, 3297. (g) Godleski, S. A.; Heacock, D. J.; McKelvey, J. M. Tetrahedron Lett. 1982, 23, 4453. (h) Truong, T.; Gordon, M. S.; Boudjouk, P. Organometallics 1984, 3, 484.

(5) (a) Angelini, G.; Keheyan, Y.; Laguzzi, G.; Lilla, G. Tetrahedron Lett. 1988, 29, 4159. (b) Shin, S. K.; Beauchamp, J. L. J. Am. Chem. Soc. 1989 111, 900 . (c) Li, X.; Stone, J. A. J. Am. Chem. Soc. 1989, 111,5586 . (d) Drewello, T.; Burgers, P. C.; Zummack, W.; Apeloig, Y.; Schwarz, H. Organometallics 1990, 9, 1161. (e) Schwarz, H. In The Chemistry of Organic Silicon Compounds; Patai, S., Rappoport, Z., Eds.; Wiley Interscience: New York, 1989; Chapter 7 and literature cited therein. (f) Okano, M.; Mochida, K. Chem. Lett. 1991, 819.
Scheme III. Relative Reactivities toward $\mathrm{AnPhCH}^{+}\left(-70^{\circ} \mathrm{C}\right)$

\begin{tabular}{lr}
\hline $\mathrm{HSiAlk}_{3}$ & \multicolumn{1}{c}{$k_{\text {rel }}$} \\
\hline $\mathrm{HSiMe}_{3}$ & $\equiv 1.00$ \\
$\mathrm{HSiEt}_{3}$ & 1.95 \\
$\mathrm{HSi}\left({ }^{n} \mathrm{Pr}\right)_{3}$ & 3.53 \\
$\mathrm{HSi}\left({ }^{n} \mathrm{Bu}\right)_{3}$ & 6.04 \\
$\mathrm{HSi}\left({ }^{n} \mathrm{Hex}\right)_{3}$ & 5.93 \\
\hline
\end{tabular}

including compounds of widely differing reactivity. ${ }^{8}$ In order to include hydrosilanes into this nucleophilicity scale, we have systematically studied the influence of the structure on the reactivities of carbenium ions and hydrosilanes, and we will present correlation equations that allow the prediction of rates for a great variety of carbenium ion hydrosilane combinations. We will report the first rate constants for mono- and disubstituted hydrosilanes and, furthermore, present evidence that requires revision of the mechanism outlined in eq 1.

\section{Method-The Role of the Negative Counterion}

The method recently described for the determination of reactivities of carbenium ions toward alkenes ${ }^{8 \mathrm{a}, \mathrm{h}}$ has analogously been used for this investigation. As previously reported, diarylmethyl halides are added to dichloromethane solutions of Lewis acids that are sufficiently strong to warrant complete ionization. In this way, colored, electrically conducting solutions of $\mathrm{Ar}_{2} \mathrm{CH}^{+} \mathrm{MY}_{n} \mathrm{X}^{-}$are produced (Scheme II). When the hydrosilanes are added, covalent products are formed (Scheme II), and the disappearance of the carbenium ions can be monitored photometrically and conductometrically.

Generally, the rate was found to depend linearly on carbenium ion and on hydrosilane concentration, as indicated by eq 2 . In accord with

$$
-\mathrm{d}\left[\mathrm{Ar}_{2} \mathrm{CH}^{+}\right] / \mathrm{d} t=k_{2}\left[\mathrm{Ar}_{2} \mathrm{CH}^{+}\right]\left[\mathrm{HSiR}_{3}\right]
$$

previous investigations, ${ }^{6 \mathrm{a}}$ the degree of ion-pairing was found not to affect the reaction rates. Identical reactivities of paired and nonpaired carbenium ions have also been observed in reactions with alkenes, and a rationalization has been given. ${ }^{8 k .9}$ Table I shows that identical rates were observed for the reaction of $\mathrm{HSiMe}_{2} \mathrm{Ph}$ with $\mathrm{An}_{2} \mathrm{CH}^{+} \mathrm{TiCl}_{5}^{-}$or $\mathrm{An}_{2} \mathrm{CH}^{+} \mathrm{OTf}^{-}$. This observation corroborates Chojnowski's conclusion that the counterion does not affect the rate-determining step. ${ }^{6 \mathrm{a}}$

Table I furthermore shows that excess $\mathrm{TiCl}_{4}$ or $\mathrm{Me}_{3}$ SiOTf, which is often necessary to achieve complete ionization of the benzhydryl chlorides, ${ }^{10}$ does not affect the rates of the reaction. When $\mathrm{BCl}_{3}$ was utilized for the ionization of $\mathrm{An}_{2} \mathrm{CHCl}$, however, the reaction was found to be 100 to 1000 times faster, depending on the concentration of $\mathrm{BCl}_{3}$ in the solution. This observation is attributed to the rapid intermediate formation of $\mathrm{HBCl}_{2},{ }^{11}$ which acts as an efficient hydride donor in the presence of $\mathrm{BCl}_{4}^{-}$

${ }^{11 B}$ NMR spectroscopy (64.1 MHz) supports this interpretation: The singlet of $\mathrm{BCl}_{3}\left(\delta 46.6 \text { with respect to external } \mathrm{BF}_{3} \cdot \mathrm{OEt}_{2}\right)^{12}$ is instanta-

(6) (a) Chojnowski, J.; Fortuniak, W.; Stanczyk, W. J. Am. Chem. Soc. 1987, 109, 7776. (b) Chojnowski, J.; Wilczek, L.; Fortuniak, W. J. Organomet. Chem. 1977, 135, 13. (c) Carey, F. A.; Wang Hsu, C.-L. J. Organomet. Chem. 1969, 19, 29. (d) Traylor, T. G.; Koermer, G. S. J. Org. Chem. $1981,46,3651$.

(7) Carey, F. A.; Tremper, H. S. J. Am. Chem. Soc. 1968, 90, 2578.

(8) (a) Schneider, R.; Grabis, U.; Mayr, H. Angew. Chem. 1986, 98, 94; Angew. Chem., Int. Ed. Engl. 1986, 25, 89. (b) Mayr, H.; Pock, R. Tetrahedron 1986, 42, 4211. (c) Mayr, H.; Pock, R. Chem. Ber. 1986, 119, 2473. (d) Mayr, H.; Pock, R. Chem. Ber, 1986, 119, 2497. (e) Schneider, R.; Mayr, H. Angew. Chem. 1986, 98, 1033; Angew. Chem., Int. Ed. Engl. 1986, 25 , 1016. (f) Mayr, H.; Schneider, R.; Grabis, U. Angew. Chem. 1986, 98, 1034; Angew. Chem., Int. Ed. Engl. 1986, 25, 1017. (g) Mayr, H.; Hagen, G. J. Chem. Soc., Chem. Commun. 1989, 91. (h) Mayr, H.; Schneider, R.; Schade, C.; Bartl, J.; Bederke, R. J. Am. Chem. Soc. 1990, 112, 4446. (i) Mayr, H.; Schneider, R.; Irrgang, B.; Schade, C. J. Am. Chem. Soc. 1990, 112, 4454 (j) Mayr, H.; Schneider, R.; Grabis, U. J. Am. Chem. Soc. 1990, 112, 4460. (k) Mayr, H. Angew. Chem. 1990, 102, 1415; Angew. Chem., Int. Ed. Engl. 1990, 29, 1371. (l) Irrgang, B.; Mayr, H. Tetrahedron 1991, 47, 219. (m) Hagen, G.; Mayr, H. J. Am. Chem. Soc. 1991, 113, 4954. (n) Bartl, J.; Steenken, S.; Mayr, H. J. Am. Chem. Soc. 1991, 113, 7710.

(9) Mayr, H.; Schneider, R.; Schade, C. Makromol. Chem. Macromol. Symp. 1988, 13/14, 43 .

(10) Schneider, R.; Mayr, H.; Plesch, P. H. Ber. Bunsenges. Phys. Chem. $1987,91,1369$

(11) Soundararajan, R.; Matteson, D. S. J. Org. Chem. 1990, 55, 2274. 
Table II. Second-Order Rate Constants for the Reactions of Diarylcarbenium Ions ${ }^{a}$ with Silanes in $\mathrm{CH}_{2} \mathrm{Cl}_{2}$ at $-70^{\circ} \mathrm{C}$

\begin{tabular}{|c|c|c|}
\hline silanes & $\begin{array}{c}\mathrm{X}, \mathrm{Y} \text { of } \\
\left(p-\mathrm{XC}_{6} \mathrm{H}_{4}\right)\left(p-\mathrm{YC}_{6} \mathrm{H}_{4}\right) \mathrm{CH}^{+}\end{array}$ & $\begin{array}{l}k_{2}\left(-70^{\circ} \mathrm{C}\right) \\
\mathrm{L} \cdot \mathrm{mol}^{-1} \cdot \mathrm{s}^{-1}\end{array}$ \\
\hline $\mathrm{HSiMe}_{3}$ & $\mathrm{OMe}, \mathrm{H}$ & $6.37 \times 10^{1}$ \\
\hline $\mathrm{HSiMe}_{2} \mathrm{Et}$ & $\mathrm{OMe}, \mathrm{H}$ & $9.06 \times 10^{1}$ \\
\hline $\mathrm{HSiMeEt}_{2}$ & $\mathrm{OMe}, \mathrm{H}$ & $1.16 \times 10^{2}$ \\
\hline $\mathrm{HSiEt}_{3}$ & $\mathrm{OMe}, \mathrm{H}$ & $1.24 \times 10^{2 b}$ \\
\hline $\mathrm{HSi}\left({ }^{n} \mathrm{Pr}\right)_{3}$ & $\mathrm{OMe}, \mathrm{H}$ & $2.25 \times 10^{2}$ \\
\hline $\mathrm{HSi}\left({ }^{(} \mathrm{Pr}\right)_{3}$ & $\mathrm{OMe}, \mathrm{H}$ & $3.67 \times 10^{1}$ \\
\hline \multirow[t]{4}{*}{$\mathrm{HSi}\left({ }^{n} \mathrm{Bu}\right)_{3}$} & $\mathrm{OMe}, \mathrm{OMe}$ & 4.30 \\
\hline & $\mathrm{OMe}, \mathrm{OPh}$ & $2.15 \times 10^{1}$ \\
\hline & $\mathrm{OMe}, \mathrm{Me}$ & $1.22 \times 10^{2}$ \\
\hline & $\mathrm{OMe}, \mathrm{H}$ & $3.85 \times 10^{2}$ \\
\hline $\mathrm{H}_{3} \mathrm{Si}\left({ }^{n} \mathrm{Hex}\right)$ & $\mathrm{OMe}, \mathrm{H}$ & $4.79 \times 10^{-2}$ \\
\hline $\mathrm{H}_{2} \mathrm{Si}\left({ }^{n} \mathrm{Hex}\right)_{2}$ & $\mathrm{OMe}, \mathrm{H}$ & 7.43 \\
\hline $\mathrm{HSi}\left({ }^{n} \mathrm{Hex}\right)_{3}$ & OMe, H & $3.78 \times 10^{2}$ \\
\hline \multirow[t]{4}{*}{$\mathrm{H}_{3} \mathrm{SiPh}$} & $\mathrm{OMe}, \mathrm{H}$ & $6.96 \times 10^{-2}$ \\
\hline & $\mathrm{OPh}, \mathrm{H}$ & $3.61 \times 10^{-1}$ \\
\hline & $\mathrm{Me}, \mathrm{Me}$ & 3.37 \\
\hline & $\mathrm{Me}, \mathrm{H}$ & $1.44 \times 10^{1}$ \\
\hline \multirow{5}{*}{$\begin{array}{l}\mathrm{H}_{2} \mathrm{SiPh}_{2} \\
\mathrm{HSiPh}_{3}\end{array}$} & OMe, $\mathrm{H}$ & 1.20 \\
\hline & $\mathrm{OMe}, \mathrm{OMe}$ & $6.52 \times 10^{-2}$ \\
\hline & $\begin{array}{l}\text { OMe, Me } \\
\text { OMe, H }\end{array}$ & $\begin{array}{l}2.22 \\
8.27^{c}\end{array}$ \\
\hline & $\begin{array}{l}\text { OMe, H } \\
\text { OPh, H }\end{array}$ & $4.52 \times 10^{1}$ \\
\hline & $\mathrm{Me}, \mathrm{Me}$ & $3.47 \times 10^{2}$ \\
\hline $\mathrm{H}_{2} \mathrm{SiMePh}$ & $\mathrm{OMe}, \mathrm{H}$ & 5.33 \\
\hline \multirow[t]{5}{*}{$\mathrm{HSiMe}_{2} \mathrm{Ph}$} & $\mathrm{OMe}, \mathrm{OMe}$ & $1.12^{d}$ \\
\hline & $\mathrm{OMe}, \mathrm{Me}$ & $3.16 \times 10^{1}$ \\
\hline & $\mathrm{OMe}, \mathrm{H}$ & $1.49 \times 10^{2 e}$ \\
\hline & $\mathrm{OPh}, \mathrm{H}$ & $6.92 \times 10^{2}$ \\
\hline & $\mathrm{Me}, \mathrm{Me}$ & $4.24 \times 10^{3}$ \\
\hline $\mathrm{HSiMe}_{2} \mathrm{Tol}$ & $\mathrm{OMe}, \mathrm{H}$ & $3.30 \times 10^{2}$ \\
\hline $\mathrm{HSiMe}_{2} \mathrm{An}$ & $\mathrm{OMe}, \mathrm{H}$ & $8.71 \times 10^{2}$ \\
\hline $\mathrm{HSiMe}_{2}\left(p-\mathrm{Cl}-\mathrm{C}_{6} \mathrm{H}_{4}\right)$ & OMe, $\mathrm{H}$ & $4.96 \times 10^{1}$ \\
\hline $\mathrm{HSiMePh}_{2}$ & OMe, $\mathrm{H}$ & $2.24 \times 10^{1}$ \\
\hline $\mathrm{HSiMe}_{2} \mathrm{CH}_{2} \mathrm{Ph}$ & $\mathrm{OMe}, \mathrm{H}$ & $2.58 \times 10^{1}$ \\
\hline $\mathrm{HSiMe}_{2} \mathrm{CH}_{2} \mathrm{Cl}$ & $\mathrm{OMe}, \mathrm{H}$ & $2.11 \times 10^{-1}$ \\
\hline $\mathrm{HSiMe}_{2} \mathrm{Cl}$ & $\mathrm{OMe}, \mathrm{H}$ & $2.1 \times 10^{-1}$ \\
\hline $\mathrm{HSiMeCl}_{2}$ & $\mathrm{Me}, \mathrm{Me}$ & $\approx 5 \times 10^{-4}$ \\
\hline $\mathrm{HSi}\left(\mathrm{SiMe}_{3}\right)_{3}$ & OMe, $\mathrm{H}$ & $4.57 \times 10^{2}$ \\
\hline $\mathrm{HSiMe}_{2}\left(\mathrm{OSiMe}_{3}\right)$ & OMe, $\mathrm{H}$ & $5.86 \times 10^{1}$ \\
\hline
\end{tabular}

${ }^{a}$ Counterion $=\mathrm{TiCl}_{5}^{-}$or $\mathrm{OTf}^{-}$, depending on the Lewis acid employed. ${ }^{b} \Delta H^{*}=(18.6 \pm 0.4) \mathrm{kJ} \cdot \mathrm{mol}^{-1} ; \Delta S^{*}=(-110 \pm 2) \mathrm{J} \cdot \mathrm{mol}^{-1} \cdot \mathrm{K}^{-1}$. ${ }^{c} \Delta H^{*}=(22.2 \pm 0.6) \mathrm{kJ} \cdot \mathrm{mol}^{-1} ; \Delta S^{*}=(-115 \pm 3) \mathrm{J} \cdot \mathrm{mol}^{-1} \cdot \mathrm{K}^{-1} \cdot{ }^{d} \Delta H^{*}$ $=(30.1 \pm 0.3) \mathrm{kJ} \cdot \mathrm{mol}^{-1} ; \Delta S^{*}=(-92.5 \pm 1.2) \mathrm{J} \cdot \mathrm{mol}^{-1} \cdot \mathrm{K}^{-1}$. ${ }^{e} \Delta H^{*}=$ $(20.0 \pm 0.5) \mathrm{kJ} \cdot \mathrm{mol}^{-1} ; \Delta S^{*}=(-102 \pm 3) \mathrm{J} \cdot \mathrm{mol}^{-1} \cdot \mathrm{K}^{-1}$.

neously replaced by a doublet $(\delta 57.5, J=200 \mathrm{~Hz})$, when $\mathrm{HSiMe}_{2} \mathrm{Ph}$ is added to the solution of $\mathrm{BCl}_{3}$ in $\mathrm{CH}_{2} \mathrm{Cl}_{2}$ at $-70^{\circ} \mathrm{C}$. When the NMR tube is opened at ambient temperature, a volatile compound is released which immediately catches fire in the air; therefore tetrachloroborates cannot be employed as counterions for kinetic investigations with hydrosilanes.

Control experiments showed that the ${ }^{1} \mathrm{H}$ NMR spectrum of $\mathrm{HSiMe}_{2} \mathrm{Ph}$ in $\mathrm{CD}_{2} \mathrm{Cl}_{2}$ is not altered, when $\mathrm{TiCl}_{4}$ or $\mathrm{Me}_{3} \mathrm{SiOTf}$ was added, indicating that these Lewis acids do not react with ordinary silanes at low temperature. Accordingly, the presence of variable amounts of these Lewis acids does not affect the reaction rates (see above). As similar observations were made for other silanes (see Supplementary Material), we can conclude that the rate constants measured in the presence of $\mathrm{TiCl}_{5}{ }^{-}$or $\mathrm{F}_{3} \mathrm{CSO}_{3}^{-}$(Table II) reflect the rate of the hydride transfer step from silicon to carbon.

\section{Variation of the Silanes}

1. Trialkylsilanes. The successive replacement of methyl by ethyl in $\mathrm{HSiMe}_{3}$ has been reported to cause a slight, but steady decrease of the hydride transfer rate to the trityl cation (Figure $\left.1, k\left(\mathrm{HSiMe}_{3}\right) / k\left(\mathrm{HSiEt}_{3}\right)=1.6\right){ }^{6 \mathrm{a}}$ Entries $1-4$ of Table II show the opposite effect on the rates of hydride abstraction by AnPhCH ${ }^{+}$. As the effects are small in both series, one can assume that the reactivity order toward the diarylcarbenium ion is con-

(12) Wrackmeyer, B.; Köster, R. NMR-Spektroskopie von Organo-BorVerbindungen, Organobor-Verbindungen III. In Houben-Weyl, Methoden der Organischen Chemie, 4th ed.; Georg Thieme Verlag: Stuttgart, 1984; Vol. XIII/3c, p 399
Scheme IV
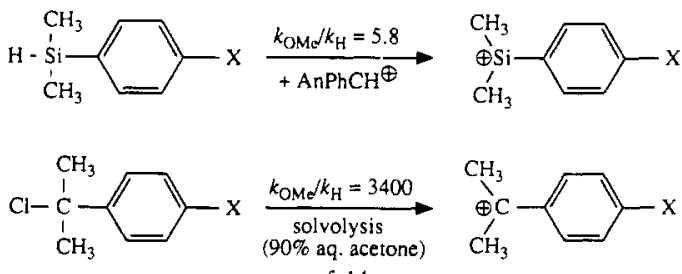

ref. 14

Scheme V. Relative Reactivities toward $\mathrm{AnPhCH}+\left(-70^{\circ} \mathrm{C}\right)$

\begin{tabular}{lcc}
\hline & $\begin{array}{c}k_{\text {rcl }} \\
\left(\mathrm{R}={ }^{n} \mathrm{Hex}\right)\end{array}$ & $\begin{array}{c}k_{\text {rel }} \\
(\mathrm{R}=\mathrm{Ph})\end{array}$ \\
\hline $\mathrm{H}_{3} \mathrm{SiR}$ & $\mathbf{a} 1.00$ & $=1.00$ \\
$\mathrm{H}_{2} \mathrm{SiR}_{2}$ & 155 & 17.2 \\
$\mathrm{HSiR}_{3}$ & 7890 & 119 \\
\hline
\end{tabular}

Scheme VI. Relative Reactivities of $\mathrm{HSiMe}_{x} \mathrm{Ph}_{3-x}$ toward $\mathrm{AnPhCH}^{+}$ $\left(-70^{\circ} \mathrm{C}\right)$

\begin{tabular}{c|cccc} 
& $\mathrm{HSiPh}_{3}$ & $\mathrm{HSiMePh}_{2}$ & $\mathrm{HSiMe}_{2} \mathrm{Ph}$ & $\mathrm{HSiMe}_{3}$ \\
\hline$k_{\text {rel }}$ & $\equiv 1.00$ & 2.71 & 18.0 & 7.70
\end{tabular}

trolled by inductive effects $\left(\sigma_{\mathrm{I}}(\mathrm{Et})=-0.055, \sigma_{\mathrm{I}}(\mathrm{Me})=-0.046\right),{ }^{13}$ which are slightly overcompensated by steric effects when the bulky triphenylcarbenium ion acts as the hydride acceptor.

Accordingly, Scheme III illustrates that hydride abstractions from tri( $n$-alkyl)silanes by $\mathrm{AnPhCH}{ }^{+}$are controlled by inductive rather than steric effects. While the increase of the chain length of the $n$-alkyl groups causes an increase of the hydride transfer rate, branching reduces the rate constants. Though isopropyl $\left(\sigma_{I}\right.$ $=-0.064)^{13}$ is a stronger inductive donor than $n$-propyl $\left(\sigma_{1}=\right.$ $-0.057),{ }^{13} \mathrm{HSi}\left({ }^{(} \mathrm{Pr}\right)_{3}$ is approximately 6 times less reactive than $\mathrm{HSi}\left({ }^{n} \mathrm{Pr}\right)_{3}$ (Table II).

2. Para-Substituted Aryldimethylsilanes: Hammett Analysis. Substituents at the aromatic ring have a relatively small effect on the rate of formation of silicenium ions. Scheme IV shows the widely differing effects which $p$-methoxy groups exert on the transition states that lead to silicenium (via hydride abstraction) and analogous carbenium ions (via $S_{N} 1$ reaction). The rate constants measured for the reaction of $\mathrm{AnPhCH}^{+}$with four aryldimethylsilanes correlate only poorly with $\sigma_{0}^{+}(r=0.95)$ but give a good correlation with $\sigma_{\mathrm{p}}(\rho=-2.46, r=0.996$, Figure 2$)$, indicating that mesomeric effects play a minor role for stabilizing silicenium ions.

3. Comparison of Alkyl and Phenyl Groups. Since exchange of hydrogen by chlorine considerably weakens the reactivity of the remaining $\mathrm{Si}-\mathrm{H}$ groups (see below), it is possible to investigate the selective abstraction of only one hydride from dihydro- and trihydrosilanes (eq 3). According to Table II, phenylsilane and

$$
\begin{array}{r}
\mathrm{H}_{3} \mathrm{SiAlkyl}+\mathrm{ArAr}^{\prime} \mathrm{CH}^{+} \mathrm{TiCl}_{5}^{-} \rightarrow \\
\mathrm{H}_{2} \mathrm{SiClAlkyl}^{-}+\mathrm{ArAr}^{\prime} \mathrm{CH}_{2}+\mathrm{TiCl}_{4}
\end{array}
$$

$n$-hexylsilane hardly differ in reactivity toward $\mathrm{AnPhCH}{ }^{+}$ $\left(k\left(\mathrm{H}_{3} \mathrm{SiPh}\right) / k\left(\mathrm{H}_{3} \mathrm{SiHex}\right)=1.5\right)$. Successive replacement of hydrogen by hexyl $\left(\mathrm{H}_{3} \mathrm{SiHex} \rightarrow \mathrm{H}_{2} \mathrm{SiHex}_{2} \rightarrow \mathrm{HSiHex}_{3}\right)$ increases the reactivity by two orders of magnitude per hexyl group while in the analogous phenyl series $\left(\mathrm{H}_{3} \mathrm{SiPh} \rightarrow \mathrm{H}_{2} \mathrm{SiPh}_{2} \rightarrow \mathrm{HSiPh}_{3}\right)$ a reactivity increase of only one order of magnitude is observed (Scheme V), with the result that the reactivity of HSiHex $_{3}$ exceeds that of $\mathrm{HSiPh}_{3}$ by almost two orders of magnitude (Table II).

With the assumption that the hydride transfer rates reflect the stabilization of the resulting silicenium ions, one would deduce that trialkyl-substituted silicenium ions are stabilized to a greater

(13) (a) Taft, R. W., Jr.; Lewis, I. C. J. Am. Chem. Soc. 1958, 80, 2436. (b) Taft, R. W., Jr.; Lewis, I. C. Tetrahedron 1959, 5, 210 . (c) Levitt, L. S.; Levitt, B. W. Chem. Ind. (London) 1970, 990. (d) Levitt, L. S.; Widing, H. F. Prog. Phys. Org. Chem. 1976, 12, 119.

(14) Brown, H. C.; Okamoto, Y. J. Am. Chem. Soc. 1958, 80, 4979. 


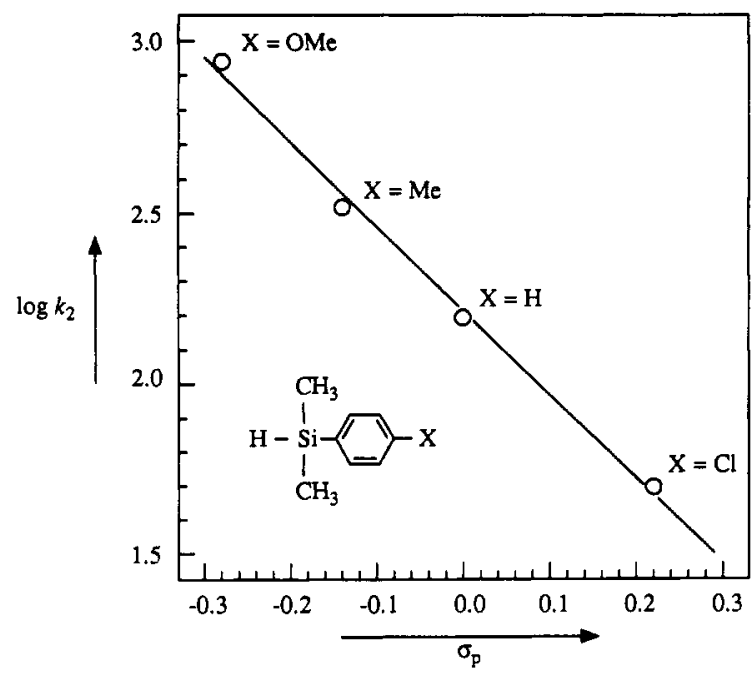

Figure 2. Correlation between the reactivities of the aryldimethylsilanes toward $\mathrm{AnPhCH}+\left(\mathrm{CH}_{2} \mathrm{Cl}_{2},-70^{\circ} \mathrm{C}\right)$ with $\sigma_{\mathrm{p}}(\rho=-2.46)$.

Table III. Calculated Stabilization Energies for Silicenium and Carbenium Ions $\left(\mathrm{kcal} \cdot \mathrm{mol}^{-1}, \mathrm{MP} 3 / 6-31 \mathrm{G}^{*} / / 6-31 \mathrm{G}^{*}\right)^{4 \mathrm{~b}}$

\begin{tabular}{lll}
\hline & \multicolumn{2}{c}{$\Delta E$} \\
\cline { 2 - 3 } $\mathbf{R}$ & eq 4 & eq 5 \\
\hline $\mathrm{CH}_{3}$ & 15.1 & 34.1 \\
$\mathrm{NH}_{2}$ & 36.8 & 97.8 \\
$\mathrm{OH}$ & 17.9 & 62.7 \\
$\mathrm{~F}$ & -2.3 & 2.1 .5 \\
$\mathrm{SiH}_{3}$ & 12.6 & 17.7 \\
$\mathrm{PH}_{2}$ & 13.5 & 60.0 \\
$\mathrm{SH}$ & 18.4 & 60.9 \\
$\mathrm{Cl}$ & 2.0 & 26.6 \\
\hline
\end{tabular}

extent than the triphenyl-substituted analogues - in contrast to the substituent effects known for carbenium ions. ${ }^{15}$ The minor importance of $\pi$-conjugation for the stabilization of silicenium ions, which is also reflected by the Hammett correlation depicted in Figure 2, has previously been deduced from ab initio $\mathrm{MO}$ calculations on HO- and HS-substituted silicenium ions. ${ }^{4 b}$

Combination of the effects responsible for the reactivity orders $\mathrm{H}_{3} \mathrm{SiAlk} \ \mathrm{H}_{3} \mathrm{SiPh}$ and $\mathrm{HSiAlk}_{3} \gg \mathrm{HSiPh}_{3}$ leads to a shallow reactivity maximum for $\mathrm{HSiMe}_{2} \mathrm{Ph}$ in the $\mathrm{HSiMe}_{x} \mathrm{Ph}_{3-x}$ series (Scheme VI).

4. Heteroatom-Substituted Silanes. According to ab initio MO calculations, substituent effects are generally greater in carbenium ions (eq 5) than in silicenium ions (eq 4, Table III). ${ }^{4 b}$

$$
\begin{aligned}
\mathrm{H}_{2} \mathrm{SiR}^{+}+\mathrm{SiH}_{4} & \rightarrow \mathrm{H}_{3} \mathrm{SiR}+\mathrm{SiH}_{3}^{+} \\
\mathrm{H}_{2} \mathrm{CR}^{+}+\mathrm{CH}_{4} & \rightarrow \mathrm{H}_{3} \mathrm{CR}+\mathrm{CH}_{3}^{+}
\end{aligned}
$$

Oxygen Substitution. The small effect of $\pi$-conjugation on silicenium ion stabilization, which has been discussed for arylsubstituted silicenium ions (see above), can also be derived from Table III. While $\mathrm{OH}$ stabilizes carbenium ions twice as much as $\mathrm{CH}_{3}$, these two substituents have a similar effect on silicenium ions. Accordingly, Chojnowski reported comparable hydride transfer rates from $\mathrm{HSiMe}_{3}$ and $\mathrm{HSiMe}_{2}\left(\mathrm{O}^{n} \mathrm{Pr}\right)$ to the trityl cation. ${ }^{6 \mathrm{~b}}$

While we were able to reproduce these results at $25^{\circ} \mathrm{C}$, we did not find second-order kinetics for the reaction of $\mathrm{HSiMe}_{2}(\mathrm{OEt})$ with $\mathrm{Ph}_{3} \mathrm{C}^{+} \mathrm{OTf}^{-}$or with diarylcarbenium triflates at low temperatures $\left(\right.$ e.g. $-70^{\circ} \mathrm{C}$ ). Our hypothesis that reversible oxonium ion formation (eq 6) was responsible for the unusual kinetic behavior of alkoxyhydrosilanes was examined by combining a tetrasubstituted silane with a carbenium salt: When $\mathrm{Me}_{3} \mathrm{SiOMe}$ was added to a solution of $\mathrm{An}_{2} \mathrm{CH}^{+} \mathrm{OTf}^{-} / \mathrm{Me}_{3} \mathrm{SiOTf}$ (excess) at $-70^{\circ} \mathrm{C}$, the carbenium ion absorbance disappeared immediately

(15) Streitwieser, A., Jr. Solvolytic Displacement Reactions; McGraw Hill: New York, 1962; p 43.
$(<5 \mathrm{~s})$ but was slowly restored to its initial value $(\approx 0.5 \mathrm{~h}) .^{16}$ Hydride transfer from alkoxysilanes, therefore, may follow a complex mechanism (eq 6), and we have excluded alkoxysilanes from this investigation.

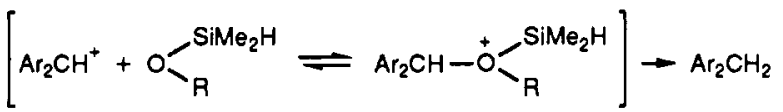

In contrast, the reaction of pentamethyldisiloxane [ $\mathrm{HSiMe}_{2} \mathrm{OSiMe}_{3}$ ] and $\mathrm{AnPhCH}{ }^{+}$at $-70^{\circ} \mathrm{C}$ follows clean second-order kinetics. Product analysis shows the formation of the corresponding diarylmethane $\mathrm{AnPhCH}_{2}$. The rate constant, which is identical for the counterions $\mathrm{TiCl}_{5}{ }^{-}$and $\mathrm{OTf}^{-}$, is very similar to that determined for hydride transfer from trimethylsilane, indicating comparable activating effects of $\mathrm{Me}$ and $\mathrm{OSiMe}_{3}$.

Amino Substitution. Analogous to the situation with alkoxysilanes, we were unable to measure hydride transfer rates from amino-substituted silanes. When $\mathrm{HSiMe}_{2}\left(\mathrm{NMe}_{2}\right)$ was added to a solution of $\mathrm{An}_{2} \mathrm{CH}^{+} \mathrm{OTf}^{-}$at $-70^{\circ} \mathrm{C}$, a rapid decrease of absorbance was observed, but product analysis showed that amino group transfer instead of hydride transfer had taken place (eq 7).

$$
\mathrm{An}_{2} \mathrm{CH}^{+} \mathrm{OTf}^{-}+\mathrm{HSiMe}_{2}\left(\mathrm{NMe}_{2}\right) \rightarrow \mathrm{An}_{2} \mathrm{CH}-\mathrm{NMe}_{2}
$$

Silyl Groups. From the calculations quoted in Table III it has been deduced that $\mathrm{CH}_{3}$ stabilizes carbenium ions considerably better than $\mathrm{SiH}_{3}$, while both groups exert a similar effect on silicenium ions. Accordingly, the superiority of $\mathrm{CH}_{3}$ over $\mathrm{SiMe}_{3}$ to stabilize carbenium ions has been observed in solvolysis reactions. ${ }^{17}$ Equal stabilizing effects of alkyl and $\mathrm{SiMe}_{3}$ on silicenium ions might now be derived from the almost identical rates of hydride transfer from $\mathrm{HSi}\left(\mathrm{SiMe}_{3}\right)_{3}$ and $\mathrm{HSi}\left({ }^{n} \mathrm{Bu}\right)_{3}$ to $\mathrm{AnPhCH}^{+}$ (Table II). It has to be noted, however, that the $\mathrm{Si}-\mathrm{H}$ bond in $\mathrm{HSi}\left(\mathrm{SiMe}_{3}\right)_{3}$ is $88 \mathrm{~kJ} \cdot \mathrm{mol}^{-1}$ weaker than that in $\mathrm{HSiEt}_{3}{ }^{18}$ so that ground-state effects cannot be ignored. One should, therefore, more precisely conclude that the relative stabilization of silanes and silicenium ions by alkyl and trialkylsilyl groups is identical. As a consequence, the large reactivity differences between trialkylsilanes and tris(trimethylsilyl)silane that have been encountered in radical reactions ${ }^{18,19}$ are not observed in ionic hydride transfer processes.

Chlorine. Whereas chlorine has been calculated to slightly stabilize silicenium ions relative to hydrogen (Table III), hydride abstraction from chlorodimethylsilane is one order of magnitude slower than that from dimethylsilane (eq 8). The rate constant

$$
\begin{gathered}
k\left(\mathrm{HSiMe}_{2} \mathrm{Cl}\right) / k\left(\mathrm{H}_{2} \mathrm{SiMe}_{2}\right) \approx 0.09 \\
{\left[\text { for } \mathrm{AnPhCH}{ }^{+},-70^{\circ} \mathrm{C}\right]}
\end{gathered}
$$

for $\mathrm{H}_{2} \mathrm{SiMe}_{2}(k \approx 2.2)$, necessary for this comparison, has been estimated from $k\left(\mathrm{H}_{2} \mathrm{SiHex}_{2}\right)$, assuming a methyl/hexyl ratio of 0.55 per alkyl group exchange (from $\mathrm{HSiMe}_{3} / \mathrm{HSiHex}_{3}$ ).

Analogously, $k\left(\mathrm{H}_{3} \mathrm{SiMe}\right) \approx 0.026$ is estimated from the value of $k\left(\mathrm{H}_{3} \mathrm{SiHex}\right)$ and linear free energy relationships (see below) were used to approximate a rate constant for $\mathrm{HSiMeCl}_{2}+$ AnPhCH ${ }^{+}\left(1.6 \times 10^{-5},-70^{\circ} \mathrm{C}\right)$ from the measured rate constant for $\mathrm{HSiMeCl}_{2}+\mathrm{Tol}_{2} \mathrm{CH}^{+}$(Table II). Equation 9 shows that

$k(\mathrm{HSiMeCl}) / k\left(\mathrm{H}_{3} \mathrm{SiMe}\right) \approx 0.0006\left[\right.$ for $\left.\mathrm{AnPhCH}{ }^{+},-70^{\circ} \mathrm{C}\right]$

replacement of two hydrogens by chlorine atoms reduces the rate of hydride transfer by more than three orders of magnitude. Smaller deactivating effects by chlorine have been reported for hydride abstractions with $\mathrm{Ph}_{3} \mathrm{C}^{+}$at $25^{\circ} \mathrm{C}^{6 \mathrm{a}}$ Accidentally, the

(16) Details of this reaction sequence have not been investigated. It is assumed, however, that the rapidly formed oxonium triflate reacts with the excess $\mathrm{Me}_{3} \mathrm{SiOTf}$ to restore the dianisylcarbenium triflate.

(17) Review: Lambert, J. B. Tetrahedron 1990, 46, 2677.

(18) Kanabus-Kaminska, J. M.; Hawari, J. A.; Griller, D.; Chatgilialoglu, C. J. Am. Chem. Soc. 1987, 109, 5267

(19) (a) Ballestri, M.; Chatgilialoglu, C.; Clark, K. B.; Griller, D.; Giese, B.; Kopping, B. J. Org. Chem. 1991, 56, 678. (b) Arya, P.; Samson, C. Lesage, M.; Griller, D. J. Org. Chem. 1990, 55, 6248 and references cited therein. 


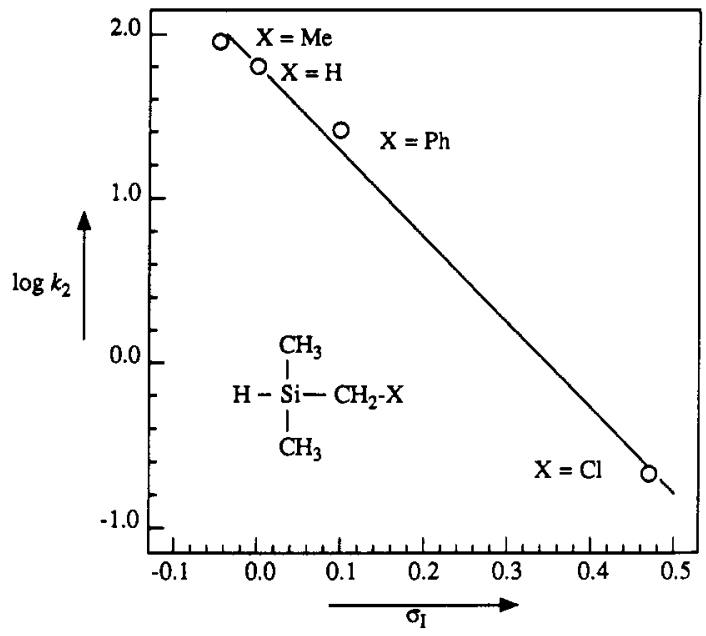

Figure 3. Correlation between the reactivities of the silanes $\mathrm{HSiMe}{ }_{2} \mathrm{CH}_{2} \mathrm{X}\left(\mathrm{AnPhCH}+\mathrm{CH}_{2} \mathrm{Cl}_{2},-70^{\circ} \mathrm{C}\right)$ with the $\sigma_{\mathrm{I}}$-values of $\mathrm{X}(\rho$ $=-5.21)$.

reactivities of $\mathrm{HSiMe}_{2} \mathrm{Cl}$ and $\mathrm{HSiMe}_{2}\left(\mathrm{CH}_{2} \mathrm{Cl}\right)$ toward $\mathrm{AnPhCH}{ }^{+}$ are identical, i.e. the stronger (-I)-effect of chlorine that is operating in the first compound, where chlorine is directly attached to silicon, must be compensated by the $\pi$-donor effect.

Figure 3 shows a linear correlation of the reactivities of the silanes $\mathrm{HSiMe}_{2}\left(\mathrm{CH}_{2} \mathrm{X}\right)$ toward $\mathrm{AnPhCH}{ }^{+}$with the inductive substituent constants $\sigma_{1}$ of $\mathrm{X}$. The positive $\sigma_{\mathrm{I}}$ values of $\mathrm{Ph}$ and $\mathrm{Cl}$ explain that benzyldimethylsilane is 2.5 times and (chloromethyl)dimethylsilane 300 times less reactive than trimethylsilane.

\section{Variation of the Hydride Acceptors}

In previous work, we found fair correlations $(r=0.97-0.991)$ between the reactivities of para-substituted diarylcarbenium ions toward $\pi$-nucleophiles (e.g. alkenes ${ }^{8 j, k}$ or allyl-element compounds ${ }^{8 m}$ ) and their $p K_{\mathrm{R}^{+-}}$-values ${ }^{20}$ or the $\mathrm{S}_{\mathrm{N}} 1$ reactivities of the corresponding benzhydryl chlorides. ${ }^{21}$ The correlations between the rate constants of these reaction series are of higher quality ( $r=0.994-0.9998)$, however. Equation 10 has been used to

$$
\log k_{2}=s \log k_{0}+c
$$

calculate rate constants $\left(k_{2},-70^{\circ} \mathrm{C}, \mathrm{CH}_{2} \mathrm{Cl}_{2}\right)$ for the reactions of benzhydryl cations with $\pi$-nucleophiles from the $\log k_{0}$ values of the benzhydryl cations (reactivity toward the reference nucleophile 2-methyl-1-pentene at $-70^{\circ} \mathrm{C}$ in $\mathrm{CH}_{2} \mathrm{Cl}_{2}$ ) and the $s$ and $c$ parameters, which have been determined for several $\pi$-nucleophiles. ${ }^{8 j, k, m}$

Accidentally, the rate constants for the attack of diarylcarbenium ions at 2-methyl-1-pentene and the silanes listed in Table II are of comparable magnitude. Correlations can, therefore, be based on the same reference electrophiles (log $k_{0}$ as in eq 10). Figure 4 and Table IV show well-behaved linear correlations between the reactivities of diarylcarbenium ions toward hydrosilanes and 2-methyl-1-pentene. The almost parallel lines in Figure 4 indicate that the relative reactivities of the hydrosilanes are independent of the electrophilicities of the hydride abstractors, i.e., selectivity is independent of reactivity. Constant selectivity relationships (Ritchie-type behavior), ${ }^{22}$ as previously reported for the reactions of benzhydryl cations with terminal vinyl compounds, are thus also observed for hydride transfer reactions. The smaller values of $s$ for the hydride transfer reactions are indicative of transition states in which charge transfer is less advanced than in the reactions of benzhydryl cations with $\pi$-nucleophiles.

(20) (a) Mindl, J.; Vecera, M. Collect. Czech. Chem. Commun. 1971, 36, 3621. (b) Deno, N. C.; Jaruzelski, J.; Schriesheim, A. J. Am. Chem. Soc. 1955, 77, 3044. (c) Dero, N. C.; Schriesheim, A. J. Am. Chem. Soc. 1955, 77,3051 .

(21) Schade, C.; Mayr, H. Tetrahedron 1988, 44, 5761.

(22) (a) Ritchie, C. D. Acc. Chem, Res. 1972, 5, 348. (b) Ritchie, C. D. Can. J. Chem. 1986, 64, 2239.
Table IV. Correlation between the Reactivities of Diarylcarbenium Ions $\left(\mathrm{ArAr}^{\prime} \mathrm{CH}^{+}\right.$) toward Hydrosilanes with the Corresponding Reactivities toward 2-Methyl-1-pentene $\left(-70^{\circ} \mathrm{C}, \mathrm{CH}_{2} \mathrm{Cl}_{2}\right)^{a}$

\begin{tabular}{lllll}
\hline \multicolumn{1}{c}{ silane } & \multicolumn{1}{c}{$s$} & \multicolumn{1}{c}{$c$} & \multicolumn{1}{c}{$r$} & no. of \\
points
\end{tabular}

${ }^{a}$ Correlation according to eq $10 ; \log k_{0}=-1.535\left(\mathrm{An}_{2} \mathrm{CH}^{+}\right)$, $-0.7721\left(\mathrm{An}(\mathrm{PhOP}) \mathrm{CH}^{+}\right), 0.5289\left(\mathrm{AnTolCH}{ }^{+}\right), 1.412\left(\mathrm{AnPhCH}^{+}\right)$, $2.456\left((\mathrm{PhOP}) \mathrm{PhCH}^{+}\right), 3.531\left(\mathrm{Tol}_{2} \mathrm{CH}^{+}\right), \sim 4.52\left(\mathrm{TolPhCH}^{+}\right) \mathrm{ex}-$ trapolated from reactivity of compound $2 \mathrm{j}$ in ref $8 \mathrm{j}$.

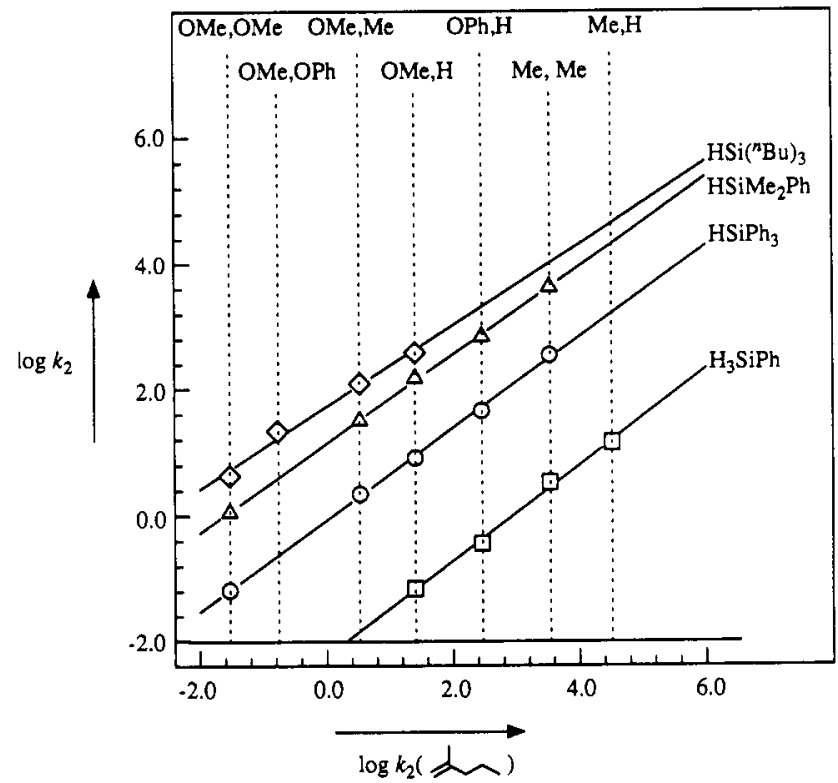

Figure 4. Correlation of the reactivities of the hydrosilanes toward diarylcarbenium ions (para substituents in figure) with the corresponding reactivites toward 2 -methyl-1-pentene $\left(\mathrm{CH}_{2} \mathrm{Cl}_{2},-70^{\circ} \mathrm{C}\right)$.

Since further hydrosilanes can be expected to possess similar $s$-values, the average value $s=0.711$ can be used to calculate $c$ for those silanes, for which only a single rate constant (usually toward $\mathrm{AnPhCH}^{+}, \log k_{0}=1.412$ ) is listed in Table II. Insertion of $s=0.711$ and $\log k_{0}=1.412$ in eq 10 yields

$$
c=\log k_{2}\left(\mathrm{AnPhCH}^{+}\right)-1.004
$$

Now, rate constants for all combinations of diarylcarbenium ions (with known reactivity toward 2-methyl-1-pentene, $\log k_{0}$ ) with hydrosilanes (with known reactivity toward one carbenium ion) can be estimated.

As hydrosilanes follow the same linear free energy relationships as $\pi$-nucleophiles, the previously derived eqs 12 and 13 can also be used for obtaining a rough approximation for the reactivity of any diarylcarbenium ion (characterized by $\mathrm{p} K_{\mathrm{R}^{+}}$or ethanolysis rate constant) toward a hydrosilane (characterized by $s$ and $c$ ).

$$
\log k_{2}\left(\mathrm{CH}_{2} \mathrm{Cl}_{2},-70^{\circ} \mathrm{C}\right)=-7.42 s-1.07 s \mathrm{p} K_{\mathrm{R}^{+}}+c
$$

$\log k_{2}\left(\mathrm{CH}_{2} \mathrm{Cl}_{2},-70^{\circ} \mathrm{C}\right)=0.90 s-1.26 s \log k_{\text {solv }}+c$

Though egs 12 and 13 have been derived for benzhydryl cations, ${ }^{8 j}$ their validity is not necessarily restricted to this class of electrophiles, and there is reason to believe that eqs 12 and 13 also hold for other types of carbenium ions, ${ }^{8 k}$ if systems with large steric requirements are excluded. When eq 12 was applied to reactions of trityl cations with $\pi$-nucleophiles, rate constants were calculated that are 3-4 orders of magnitude greater than the experimentally determined values. ${ }^{23}$ It has been concluded, therefore, that the 477.

23) Schade, C.; Mayr, H. Makromol. Chem., Rapid Commun. 1988, 9 , 
Table V. Calculated (eq 12) and Experimental Rate Constants for the Hydride Abstraction by the Trityl Cation $\left(\mathrm{Ph}_{3} \mathrm{C}^{+},-70^{\circ} \mathrm{C}\right.$, $\mathrm{CH}_{2} \mathrm{Cl}_{2}$ )

\begin{tabular}{lll}
\hline \multicolumn{1}{c}{ silane } & $k_{2}(\mathrm{calc})^{a}$ & $k_{2}$ (exp) \\
\hline $\mathrm{HSiEt}_{3}$ & $7.24^{b}$ & $0.268^{c}$ \\
$\mathrm{HSiMe}_{2} \mathrm{Ph}$ & 8.7 & 0.175 \\
$\mathrm{HSiMe}_{2} \mathrm{Cl}$ & $0.012^{b}$ & 0.0031 \\
\hline
\end{tabular}

${ }^{a} \mathrm{p} K_{\mathrm{R}^{+}}=-6.63$ (ref 20). ${ }^{b} s=0.710$ (average). ${ }^{c} \Delta H^{*}=31.8 \pm 0.5$ $\mathrm{kJ} \cdot \mathrm{mol}^{-1}, \Delta S^{*}=-96.1 \pm 2.1 \mathrm{~J} \cdot \mathrm{mol}^{-1} \cdot \mathrm{K}^{-1}$.

electrophilicity of trityl cations is strongly reduced by steric factors.

Table $\mathrm{V}$ shows that steric effects play a minor role in hydride transfer reactions. The experimentally determined rate constants for hydride abstractions by $\mathrm{Ph}_{3} \mathrm{C}^{+}$are just 1-2 orders of magnitude smaller than those calculated on the basis of eq 12. As trityl cations are the carbenium ions that showed the greatest deviations from linear free energy relationships for additions to $\pi$-systems, ${ }^{8 \mathrm{k}}$ it can be expected that eqs 12 and 13 provide good estimates for the rates of hydride abstractions by most types of carbenium ions.

\section{Reaction Mechanism. Evidence against SET Processes}

In accord with a rate-determining step, in which charge separation is neither created nor deleted, the rate of hydride transfer from $\mathrm{HSiMe} \mathrm{Ph}_{2}$ to $\mathrm{An}_{2} \mathrm{CH}^{+}$is almost equal in solvents of different polarity, ranging from dichloromethane to nitromethane (Table VI). This behavior is in agreement with the polar as well as the SET mechanism.

Kinetic isotope effects should be able to differentiate these two possibilities, because only in the polar mechanism does cleavage of the $\mathrm{Si}-\mathrm{H}$ bond occur in the rate-determining step. The first four entries of Table VII show $k_{\mathrm{H}} / k_{\mathrm{D}}$ ratios of approximately 2 $\left(-70^{\circ} \mathrm{C}\right)$, in accordance with Chojnowski's data $\left(k_{\mathrm{H}} / k_{\mathrm{D}}=1.4-\right.$ $1.5),{ }^{6 \mathrm{a}}$ which refer to $25^{\circ} \mathrm{C}$. Only small, unsystematic changes of $k_{\mathrm{H}} / k_{\mathrm{D}}$ were observed, when the electrophilicity of the hydride abstractor was varied by four orders of magnitude (see hydride abstractions from $\mathrm{HSiPh}_{3}$, Table VII).

Chojnowski interpreted the observed $k_{\mathrm{H}} / k_{\mathrm{D}}$ ratios as secondary deuterium isotope effects and considered the independence of the isotope effects of the reactivity as support for the suggested SET mechanism. ${ }^{6 a}$ Since we doubted this interpretation, we have synthesized mono- and dideuteriodiphenylsilanes, in order to identify the origin of the isotope effects.

If the observed isotope effects were secondary effects, $k\left(\mathrm{H}_{2} \mathrm{SiPh}_{2}\right) / k\left(\mathrm{HDSiPh}_{2}\right)$ should be similar to that observed for compounds $\mathrm{HSiR}_{3} / \mathrm{DSiR}_{3}$, and $k\left(\mathrm{H}_{2} \mathrm{SiPh}_{2}\right) / k\left(\mathrm{D}_{2} \mathrm{SiPh}_{2}\right)$ should be the square of this ratio (i.e. 3 to 4.5). Table VII shows that this is not the case and that the last two entries show much smaller isotope effects than expected on the basis of this hypothesis.

A consistent scheme arises, however, if rate-determining $\mathrm{Si}-\mathrm{H}$ cleavage is assumed. In this case, the product ratio obtained by reaction of $\mathrm{HDSiPh}_{2}$ with $\mathrm{AnPhCH} \mathrm{H}^{+}$must reflect the ratio of the kinetically determined rate constants.

When $\mathrm{HDSiPh}_{2}$ was treated with $\mathrm{AnPhCH}{ }^{+}$, hydride and deuteride transfer took place in a 1.82:1 ratio (eq 14). This ratio

$$
\mathrm{HDSiPh}_{2}+\mathrm{AnPhCH}^{+} \rightarrow \mathrm{AnPhCH}_{2}+\mathrm{AnPhCHD}
$$

1.82:1

is used to split the kinetically determined rate constant for $\mathrm{HDSiPh}_{2}$ (Table VII) into the partial rate constants shown in Scheme VII. The ratios of the upper right and the lower left partial rate constants of Scheme VII $(2.06 \pm 0.05)$ now correspond to the primary isotope effect, and the ratios of the upper left and lower right rate constants $(1.13 \pm 0.03)$ correspond to the secondary isotope effect. As expected for a mechanism with ratedetermining Si-H cleavage, the primary kinetic isotope effect thus derived is of similar size as the $k_{\mathrm{H}} / k_{\mathrm{D}}$ ratio for trisubstituted silanes.

(24) Reichardt, C. Solvents and Solvent Effects in Organic Chemistry, 2nd ed.; VCH.Verlagsgesellschaft: Weinheim, 1988.

(25) (a) Collins, C. J.; Bowman, N. S., Eds. Isotope Effects in Chemical Reactions; ACS Monograph 167; American Chemical Society: Washington. DC, 1970. (b) Scheppele, S. E. Chem. Rev. 1972, 72, 511.

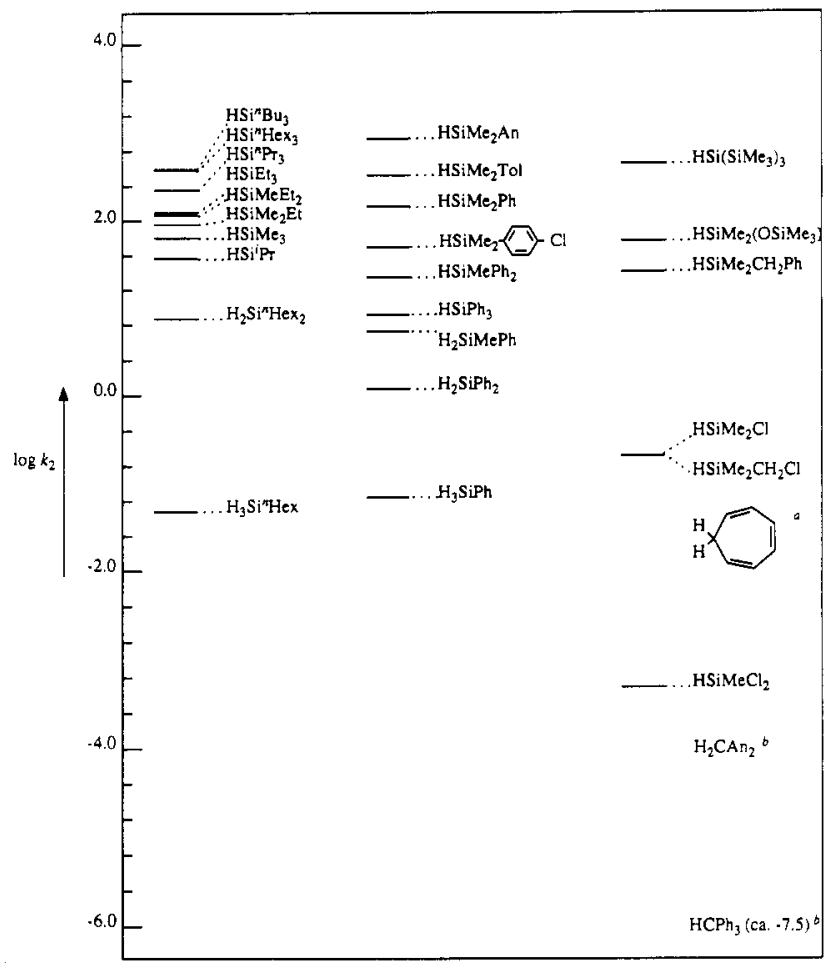

Figure 5. Comparison of hydride transfer rates from hydrosilanes and some hydrocarbons to AnPhCH ${ }^{+}\left(\mathrm{CH}_{2} \mathrm{Cl}_{2},-70^{\circ} \mathrm{C}\right)$. Superscript $a$ designates data estimated from LFER in ref 29 assuming $\Delta S^{*}=-110$ $\mathrm{J} \cdot \mathrm{mol}^{-1} \cdot \mathrm{K}^{-1}$. Superscript $b$ designates data estimated from LFER in ref 30 assuming $\Delta S^{*}=-110 \mathrm{~J} \cdot \mathrm{mol}^{-1} \cdot \mathrm{K}^{-1}$.

Scheme VII. Partial Rate Constants $\left(k_{2}, \mathrm{~L} \cdot \mathrm{mol}^{-1} \cdot \mathrm{s}^{-1}\right)$ for the Reactions of $\mathrm{AnPhCH}^{+}$with Mono-, Di-, and Nondeuteriated Diphenylsilane $\left(\mathrm{CH}_{2} \mathrm{Cl}_{2},-70^{\circ} \mathrm{C}\right)$

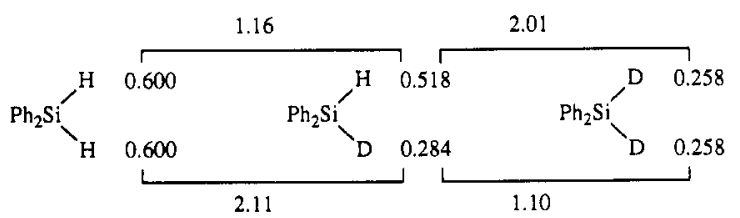

If one were to adhere to the mechanism with rate-determining single-electron transfer and successive hydron shift (eq 1), one would not only have to explain the enormous size of the secondary isotope effect but also the different magnitude of $k_{\mathrm{H}} / k_{\mathrm{D}}$ for diand trisubstituted silanes. Furthermore, one would have to postulate that the coincidence of the $k_{\mathrm{H}} / k_{\mathrm{D}}$ ratios determined by rate (Table VII) and by product studies (eq 14) were entirely accidental.

\section{Conclusion}

The kinetic isotope effects are in accord with the polar mechanism illustrated in Scheme II but not with the SET process formulated in eq 1. This result is not unexpected in view of the fact that the ionization potentials of silanes $\left(\mathrm{Ph}_{-} \mathrm{SiH}_{3}, 9.18 \mathrm{eV}\right.$;

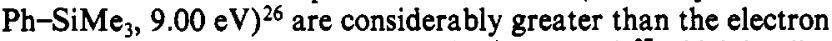
affinities of benzhydryl cations $\left(\mathrm{Ph}_{2} \mathrm{CH}^{+}, 7.32 \mathrm{eV}\right),{ }^{27}$ which implies that SET is energetically unfavorable.

In the polar mechanism, hydride transfer takes place in the rate-determining step, and it may be assumed that the stabilization of the silicenium ions thus produced is reflected by the reaction rates. Most of the preceding discussions on substituent effects have, therefore, implied the proportionality between $\Delta G^{*}$ and $\Delta G^{\circ}$ of the rate-determining step (Bell-Evans-Polanyi principle). ${ }^{28}$

26) Frey, J. E. Appl. Spectrosc. Rev. 1987, 23, 247.

(27) Franklin, J. L. In Carbonium Ions; Olah, G. A., Schleyer P. v. R., Eds.; Wiley-Interscience: New York, 1968; Vol. 1, Chapter 2.

(28) For an excellent discussion see: Dewar, M. J. S.; Dougherty, R. C The PMO-Theory of Organic Chemistry; Plenum Press: New York, 1975; p 218. 
Table VI. Reaction of Bis(p-methoxyphenyl)carbenium Triflate $\left(\mathrm{An}_{2} \mathrm{CH}^{+} \mathrm{OTf}\right)$ with Dimethylphenylsilane in Various Solvents ${ }^{a}$

\begin{tabular}{cccccccc}
\hline solvent & $\epsilon^{b}$ & $E_{\mathrm{T}}(30)^{c}$ & temp range, ${ }^{\circ} \mathrm{C}$ & $\begin{array}{c}\Delta H^{*}, \\
\mathrm{~kJ} \cdot \mathrm{mol}^{-1}\end{array}$ & $\begin{array}{c}\Delta S^{*}, \\
\mathrm{~J} \cdot \mathrm{mol}^{-1} \cdot \mathrm{K}^{-1}\end{array}$ & $\begin{array}{c}\Delta G^{*}\left(-20^{\circ} \mathrm{C}\right), \\
\mathrm{kJ} \cdot \mathrm{mol}^{-1}\end{array}$ & $\begin{array}{c}k_{2}\left(-20{ }^{\circ} \mathrm{C}\right), \\
\mathrm{L} \cdot \mathrm{mol}^{-1} \cdot \mathrm{s}^{-1}\end{array}$ \\
\hline $\mathrm{CH}_{2} \mathrm{Cl}_{2}$ & 8.9 & 40.7 & -70 to +10 & 30.1 & -92.5 & 53.5 & 47.7 \\
$\left(\mathrm{CH}_{2} \mathrm{Cl}\right)_{2}$ & 10.37 & 41.3 & -20 to +30 & 27.9 & -98.2 & 52.8 & 68.4 \\
$\mathrm{H}_{3} \mathrm{C}-\mathrm{CN}$ & $37.5^{d}$ & 46.0 & -20 to +30 & 27.6 & -99.5 & 52.8 & 67.5 \\
$\mathrm{H}_{3} \mathrm{C}-\mathrm{NO}_{2}$ & 35.94 & 46.3 & -10 to +20 & 35.1 & -69.4 & 52.7 & 71.4 \\
\hline
\end{tabular}

${ }^{a}\left[\mathrm{An}_{2} \mathrm{CH}^{+}\right]_{0}$
${ }_{20}{ }^{\circ} \mathrm{C}$.

Table VII. Rate Constants for the Reactions of Diarylcarbenium Ions $\left[\left(p-\mathrm{XC}_{6} \mathrm{H}_{4}\right)\left(p-\mathrm{YC}_{6} \mathrm{H}_{4}\right) \mathrm{CH}^{+}\right]$with Deuteriosilanes in $\mathrm{CH}_{2} \mathrm{Cl}_{2}$ at $-70^{\circ} \mathrm{C}$

\begin{tabular}{|c|c|c|c|}
\hline silane & $X, Y$ & $\begin{array}{c}k_{2}, \\
\mathrm{~L} \cdot \mathrm{mol}^{-1} \cdot \mathrm{s}^{-1}\end{array}$ & $k_{\mathrm{H}} / k_{\mathrm{D}}$ \\
\hline $\mathrm{DSiEt}_{3}$ & OMe, $\mathrm{H}$ & 73.6 & 1.68 \\
\hline $\mathrm{DSiMe}_{2} \mathrm{Ph}$ & $\mathrm{OMe}, \mathrm{H}$ & 75.8 & 1.97 \\
\hline $\mathrm{DSiPh}_{3}$ & $\mathrm{OMe}, \mathrm{H}$ & 4.38 & 1.89 \\
\hline $\mathrm{DSi}\left({ }^{i} \mathrm{Pr}\right)_{3}$ & $\mathrm{OMe}, \mathrm{H}$ & 17.3 & 2.09 \\
\hline $\mathrm{DSiPh}_{3}$ & $\mathrm{OMe}, \mathrm{OMe}$ & 0.0305 & 2.14 \\
\hline $\mathrm{DSiPh}_{3}$ & $\mathrm{Me}, \mathrm{Me}$ & 168 & 2.07 \\
\hline $\mathrm{HDSiPh}_{2}$ & $\mathrm{OMe}, \mathrm{H}$ & 0.802 & 1.50 \\
\hline $\mathrm{D}_{2} \mathrm{SiPh}_{2}$ & $\mathrm{OMe}, \mathrm{H}$ & 0.516 & 2.33 \\
\hline
\end{tabular}

While this relationship has been found to hold roughly for hydride abstractions from $\mathrm{CH}$ groups, i.e. hydride transfer is usually the faster the better stabilized the produced carbenium ion, ${ }^{29}$ deviations from the proportionality between $\Delta \mathrm{p} K_{\mathrm{R}^{+}}$and $\log k$ (hydride transfer) have been reported. ${ }^{30}$ Figure 5, for example, which compares hydride transfer rates from $\mathrm{SiH}$ and some $\mathrm{CH}$ groups, shows that triphenylmethane is a considerably less active hydride donor than bis(p-anisyl)methane though the resulting carbenium ions differ by less than one $\mathrm{p} K_{\mathrm{R}^{+}}$unit. Caution is necessary, therefore, when thermodynamic properties are being derived from these kinetic data.

\section{Experimental Section}

For the kinetic experiments the previously described apparatus and methods have been used. ${ }^{\text {gh }}$ The silanes were either commercially available or synthesized by $\mathrm{LiAlH}_{4}$ (or $\mathrm{LiAlD}_{4}$ ) reduction of the corresponding chlorosilanes.

The partial rate constants for the reaction of $\mathrm{HDSiPh}_{2}$ with $\mathrm{AnPhCH}^{+}$ were obtained by mass spectroscopic determination of the product ratio $\mathrm{AnPhCH} / \mathrm{AnPhCHD}$ (EI, $70 \mathrm{eV}$ ). For this purpose the relative intensities of the peaks with $m / e=197,198,199$, and 200 were determined for $\mathrm{AnPhCH}_{2}$ (39.0:100:14.9:1.17) and AnPhCHD (5.63:38.0:100:14.9) Three mixtures with molar ratio $\mathrm{AnPhCH}_{2} / \mathrm{AnPhCHD}$ from 0.5 to 2.5 have then been prepared, and the product ratio $\mathrm{H} / \mathrm{D}$ ( $\mathrm{H}$ for $\mathrm{AnPhCH}_{2}$ $\mathrm{D}$ for $\mathrm{AnPhCHD}$ ) has been calculated by solving the following system of linear equations for the intensities $I$ of the peaks with $m / e=197-200$, using the method of least squares:

$$
\begin{aligned}
& 39 \mathrm{H}+5.63 \mathrm{D}=I(197) \\
& 100 \mathrm{H}+38.0 \mathrm{D}=I(198) \\
& 14.9 \mathrm{H}+100 \mathrm{D}=I(199) \\
& 1.17 \mathrm{H}+14.9 \mathrm{D}=I(200)
\end{aligned}
$$

(29) Dauben, H. J.: McDonough, L. M. Unpublished results. McDonough, L. M. Ph.D. Thesis, University of Washington, 1960.

(30) Bethell, D.; Hare, G. J.; Kearney, P. A. J. Chem. Soc., Perkin Trans. 21981,684 .
The deviation between calculated and experimental product ratios was $2-3 \%$.

Three competition experiments $\left(\mathrm{AnPhCH}{ }^{+} \mathrm{TiCl}_{5}^{-}\right.$was combined with 1:1 to 4:1 mixtures of $\mathrm{D}_{2} \mathrm{SiPh}_{2}$ and $\left.\mathrm{H}_{2} \mathrm{SiPh}_{2}\right)$ were then carried out to give relative reactivities $k\left(\mathrm{H}_{2} \mathrm{SiPh}_{2}\right) / k\left(\mathrm{D}_{2} \mathrm{SiPh}_{2}\right)=2.30,2.25$, and 2.10 , in good agreement with the reactivity ratio, determined by kinetic measurements $(2.33$, Table VII). With the method thus confirmed, the intramolecular competition experiment has been performed: $\mathrm{AnPhCHCl}$ $(0.859 \mathrm{mmol})$ was dissolved in $90 \mathrm{~mL}$ of $\mathrm{CH}_{2} \mathrm{Cl}_{2}$ at $-78^{\circ} \mathrm{C}\left(\mathrm{N}_{2}\right.$ atmosphere), and a solution of $\mathrm{HDSiPh}_{2}(1.79 \mathrm{mmol})$ in $\mathrm{CH}_{2} \mathrm{Cl}_{2}(2 \mathrm{~mL})$ was added. After the addition of $\mathrm{TiCl}_{4}(0.2 \mathrm{mmol})$, the mixture was kept at $-78^{\circ} \mathrm{C}$ for $15 \mathrm{~h}$ and then poured into concentrated aqueous ammonia $(100 \mathrm{~mL})$. After extraction with $\mathrm{CH}_{2} \mathrm{Cl}_{2}(3 \times 50 \mathrm{~mL})$, the solution was dried over $\mathrm{CaCl}_{2}$ and evaporated, and the residue was analyzed by $\mathrm{GC} / \mathrm{MS}$. Since the $\mathrm{AnPhCH} / \mathrm{AnPhCHD}$ peak obtained by GC showed an inhomogeneous isotope distribution, the mass spectra summarized over the whole GC peak were evaluated (the same procedure has been used for confirming the method). From the peaks $m / e$ (relative intensity) $=$ $197(35.4), 198(100), 199(58.0)$, and $200(7.87)$ a reactivity ratio of 1.82 is calculated, which allows the measured rate constants to be split into the partial rate constants 0.284 (for $\mathrm{D}$ abstraction) and 0.518 (for $\mathrm{H}$ abstraction).

Acknowledgment. We thank Ms. Andrea Riemann for the mass spectroscopic analysis, Dr. E. Popowski (Rostock) for a generous gift of pentamethyldisiloxane and Mr. S. Seifert for improving the software to control the work station for the kinetic experiments. Financial support by the Deutsche Forschungsgemeinschaft and the Fonds der Chemischen Industrie is gratefully acknowledged.

Registry No. HSiMe ${ }_{3}, 993-07-7$; $\mathrm{HSiMe}_{2} \mathrm{Et}, 758-21-4$; $\mathrm{HSiMeEt}_{2}$, 760-32-7; $\mathrm{HSiEt}_{3}, 617-86-7$; $\mathrm{HSi}\left({ }^{(} \mathrm{Pr}\right)_{3}, 998-29-8 ; \mathrm{HSi}\left({ }^{(} \mathrm{Pr}\right){ }_{3}, 6485-79-6$; $\mathrm{HSi}\left({ }^{n} \mathrm{Bu}\right)_{3}, 998-41-4 ; \mathrm{H}_{3} \mathrm{Si}\left({ }^{n} \mathrm{Hex}\right), 1072-14-6 ; \mathrm{H}_{2} \mathrm{Si}\left({ }^{n} \mathrm{Hex}\right)_{2}, 1002-78-4 ;$ $\mathrm{HSi}\left({ }^{n} \mathrm{Hex}\right)_{3}, 2929-52-4 ; \mathrm{H}_{3} \mathrm{SiPh}, 694-53-1 ; \mathrm{H}_{2} \mathrm{SiPh}_{2}, 775-12-2 ; \mathrm{HSiPh}_{3}$, 789-25-3; $\mathrm{H}_{2} \mathrm{SiMePh}, 766-08-5$; $\mathrm{HSiMe}_{2} \mathrm{Ph}, 766-77-8 ; \mathrm{HSiMe}_{2} \mathrm{Tol}$, 1432-39-9; $\mathrm{HSiMe}_{2} \mathrm{An}, 1432-38-8 ; \mathrm{HSiMe}_{2}\left(p-\mathrm{Cl}_{-} \mathrm{C}_{6} \mathrm{H}_{4}\right), 1432-31-1$; HSiMePh, $776-76-1$; $\mathrm{HSiMe}_{2} \mathrm{CH}_{2} \mathrm{Ph}, 1631-70-5 ; \mathrm{HSiMe}_{2} \mathrm{CH}_{2} \mathrm{Cl}$, 3144-74-9; $\mathrm{HSiMe}_{2} \mathrm{Cl}, 1066-35-9 ; \mathrm{HSiMeCl}_{2}, 75-54-7 ; \mathrm{HSi}\left(\mathrm{SiMe}_{3}\right)_{3}$, 1873-77-4; $\mathrm{HSiMe}_{2}\left(\mathrm{OSiMe}_{3}\right), 1438-82-0$; $\mathrm{DSiEt}_{3}, 1631-33-0$; $\mathrm{DSiMe}_{2} \mathrm{Ph}$, 22034-19-1; $\mathrm{DSiPh}_{3}, 18536-60-2$; DSi $\left({ }^{\mathrm{P} r}\right)_{3}, 139408-37-0$; $\mathrm{HDSiPh}_{2}$, 126971-98-0; $\mathrm{D}_{2} \mathrm{SiPh}_{2}, 17950-94-6 ; \mathrm{AnPhCH}^{+}, 13270-92-3 ; \mathrm{An}_{2} \mathrm{CH}^{+}$, 13948-07-7; $\mathrm{An}\left(p-\mathrm{PhOC}_{6} \mathrm{H}_{4}\right) \mathrm{CH}^{+}$, 99796-93-7; $\mathrm{AnTolCH}^{+}, 42289-58-7$; $\mathrm{Ph}\left(p-\mathrm{PhOC}_{6} \mathrm{H}_{4}\right) \mathrm{CH}^{+}, 104910-81-8$; $\mathrm{Tol}_{2} \mathrm{CH}^{+}, 58493-75-7$; $\mathrm{PhTolCH}{ }^{+}$, 42289-57-6; $\mathrm{MeSiH}_{2}^{+}, 27516-00-3$; $\left(\mathrm{H}_{2} \mathrm{~N}\right) \mathrm{SiH}_{2}^{+}, 66639-71-2$; (HO)$\mathrm{SiH}_{2}{ }^{+}, 66639-72-3$; $\mathrm{FSiH}_{2}{ }^{+}, 68992-43-8$; $\left(\mathrm{H}_{3} \mathrm{Si}\right) \mathrm{SiH}_{2}{ }^{+}, 86860-82-4$; $\left(\mathrm{H}_{2} \mathrm{P}\right) \mathrm{SiH}_{2}{ }^{+}, 80401-42-9$; ( $\left.\mathrm{HS}\right) \mathrm{SiH}_{2}{ }^{+}, 80401-43-0 ; \mathrm{ClSiH}_{2}{ }^{+}, 80401-44-1$; $\mathrm{MeCH}_{2}{ }^{+}, 14936-94-8 ;\left(\mathrm{H}_{2} \mathrm{~N}\right) \mathrm{CH}_{2}{ }^{+}, 54088-53-8$; (HO) $\mathrm{CH}_{2}{ }^{+}, 17691-$ 31-5; $\mathrm{FCH}_{2}{ }^{+}, 35310-31-7$; $\left(\mathrm{H}_{3} \mathrm{Si}\right) \mathrm{CH}_{2}{ }^{+}, 53696-43-8 ;\left(\mathrm{H}_{2} \mathrm{P}\right) \mathrm{CH}_{2}{ }^{+}$, $111129-73-8$; (HS) $\mathrm{CH}_{2}{ }^{+}$, 20879-50-9; $\mathrm{ClCH}_{2}^{+}, 59000-00-9$.

Supplementary Material Available: Tables with concentrations and rate constants of the kinetic experiments described in Tables I, II, V, VI, and VII (19 pages). Ordering information is given on any current masthead page. 